\title{
STUDI SUHU DAN pH GELATINISASI PADA PEMBUATAN BIOPLASTIK DARI PATI KULIT SINGKONG
}

\author{
Dewa Made Dwi Pradana Putra, Bambang Admadi Harsojuwono*, Amna Hartiati \\ PS Teknologi Industri Pertanian, Fakultas Teknologi Pertanian, Universitas Udayana, Kampus Bukit \\ Jimbaran, Badung, Kode pos : 80361; Telp/Fax : (0361) 701801.
}

Diterima 09 April 2019 / Disetujui 30 April 2019

\begin{abstract}
The purpose of this study was to determine the effect of temperature and $\mathrm{pH}$ on the gelatinization process of cassava peel starch on the characteristics of bioplastics and determine the temperature and $\mathrm{pH}$ in the gelatinization process of cassava peel starch to produce the best characteristics of bioplastics. This research was carried out in the Faculty Food Analysis laboratory, Agricultural Technology Natural Resources (PSDA) laboratory, Production Laboratory of the Faculty of Engineering and Bioscience laboratory, Udayana University. This research was conducted from February to March 2018. The experimental design in this study was factorial Randomized Block Design (RBD) with two factors. Based on the analysis in the research conducted, getting conclusions, namely temperature and $\mathrm{pH}$ and their interactions have a large influence on tensile strength, elongation and elution, in the manufacture of bioplastics from cassava peel starch and samples of best cassava peel starch bioplastic found at a temperature ratio of $75^{\circ}$ and $\mathrm{pH} 5$ with a tensile strength characteristic of $1.181 \mathrm{Mpa}$, the breakdown extension was $13.591 \%$ and the elasticity was $8.744 M P a$.
\end{abstract}

Keywords : temperature, $\mathrm{pH}$, gelatinization, bioplastics

*Korespondensi Penulis:

Email : bambang.admadi@unud.ac.id 


\section{PENDAHULUAN}

Penggunaan plastik telah meluas hampir ke seluruh bidang kehidupan. Berbagai produk dan peralatan dihasilkan dari bahan plastik karena dinilai lebih ekonomis, tidak mudah pecah, fleksibel, dan ringan. Menurut Asosiasi Industri Ofelin Aromatik dan Plastik Indonesia (Inaplas) tahun 2012, penggunaan plastik pada tahun 2013 mencapai 10,75 kg/kapita. Potensi peningkatan permintaan plastik kemasan masih cukup besar, yakni sekitar 4,6 juta ton/tahun dengan pertumbuhannya sekitar 5\% pertahun (Kasmiati, 2013).

Pati merupakan salah satu senyawa bahan alam terbaharui yang paling banyak dikembangkan untuk plastik. Potensi penggunaan pati sebagai bahan bioplastik berkisar $80-95 \%$ dari pasar bioplastik yang ada. Sumber pati yang banyak digunakan yaitu pati ubi kayu (singkong), gandum dan kentang (Vilpoux and Averous, 2004), Firdaus dan Anwar (2014), menyatakan jenis pati yang potensial sebagai bahan baku plastik biodegradable adalah pati singkong atau tapioka.

Ketersedian singkong di Indonesia cukup tinggi, Data Badan Pusat Statistik (2013) menyatakan produksi singkong mencapai 24 juta ton. Hal ini menyisakan permasalahan lingkungan, yaitu limbah berupa kulit singkong. Kulit singkong mencapai 10-20\% dari umbi, dan lapisan periderm mencapai $0,5-2,0 \%$ dari total berat umbi, lapisan cortex yang berwarna putih mencapai 8-19,5\% (Supriyadi, 1995). Dengan data tersebut maka limbah kulit singkong mencapai $2,4-4,8$ juta ton per tahun. Berdasarkan penelitian pendahuluan dari $1 \mathrm{~kg}$ kulit singkong diperoleh pati sebesar $9 \%$ dengan demikian potensi pati dari kulit singkong mencapai $172.800-421.200$ ton per tahun. Grace (1997) menyatakan dalam 100 gram kulit singkong mengandung pati 15-20 gram. Potensi pati kulit singkong yang sangat besar dapat dikembangkan menjadi bahan baku bioplastik.

Bagian dari singkong yang dianggap limbah jika tidak dimanfaatkan yaitu kulit singkong, yang merupakan limbah kupasan hasil pengolahan gaplek, tapioka, tape, dan panganan berbahan dasar singkong lainnya. Oleh karena itu, bahan ini masih belum banyak dimanfaatkan dan dibuang begitu saja dan umumnya hanya digunakan sebagai pakan ternak. Kulit singkong dapat menjadi produk yang bernilai ekonomis tinggi, antara lain diolah menjadi tepung mocaf. Persentase kulit singkong kurang lebih 20\% dari umbinya sehingga per $\mathrm{kg}$ umbi singkong menghasilkan 0,2 kg kulit singkong.

Bioplastik adalah plastik yang dapat digunakan seperti layaknya plastik konvensional, namun akan hancur terurai oleh aktivitas mikroorganisme menjadi air dan karbondioksida setelah habis terpakai dan dibuang ke lingkungan. Bahan penyusun bioplastik ini berasal dari alam seperti pati dan selulosa sehingga mudah diuraikan kembali (Yuniarti et al., 2014). Plastik biodegradable adalah suatu bahan dalam kondisi tertentu dan pada waktu tertentu mengalami perubahan dalam struktur fisis dan kimianya karena pengaruh mikroorganisme yang kemudian mempengaruhi sifat-sifat yang dimilikinya (Griffin, 1994). Sifatnya yang dapat kembali ke alam, maka dikategorikan sebagai plastik yang ramah lingkungan (Firdaus dan Anwar, 2014).

Beberapa penelitian terdahulu telah dilakukan untuk menghasilkan bioplastik dari pati kulit singkong, namun masih terdapat beberapa kekurangan pada karakteristik fisik dan mekaniknya yang masih rendah, karena banyak tahap yang belum optimal diantaranya suhu dan $\mathrm{pH}$ pada proses gelatinisasi pada pembuatan bioplastik. Pembentukan gel ini dipengaruhi pula oleh pH larutan. Pembentukan gel optimum pada $\mathrm{pH}$ 4-7. Bila $\mathrm{pH}$ terlalu tinggi, pembentukan 
gel makin cepat tercapai tapi cepat turun lagi, sedangkan bila $\mathrm{pH}$ terlalu rendah terbentuknya gel lambat dan bila pemanasan diteruskan, viskositas akan turun lagi (Winarno, 1991). Optimalisasi penggunaan suhu dan $\mathrm{pH}$ pada proses gelatinisasi diharapkan dapat meningkatkan sifat fisik dan mekanik bioplastik.

Penelitian ini bertujuan untuk mengetahui pengaruh suhu dan $\mathrm{pH}$ pada proses gelatinisasi pati kulit singkong terhadap karakteristik bioplastik dan menentukan suhu dan $\mathrm{pH}$ pada proses gelatinisasi pati kulit singkong yang tepat untuk menghasilkan karakteristik bioplastik terbaik.

\section{METODE PENELITIAN}

\section{Tempat dan Waktu Penelitian}

Penelitian ini dilaksanakan di laboratorium Analisis Pangan Fakultas, laboratorium Pengolahan Sumber Daya Alam (PSDA) Teknologi Pertanian, laboratorium Produksi Fakultas Teknik dan laboratorium Biosains, Universitas Udayana. Penelitian ini dilaksanakan pada bulan Februari sampai dengan bulan Maret 2018.

\section{Bahan dan Alat}

Bahan yang digunakan yaitu pati kulit singkong putih. Kulit singkong putih diperoleh di penjual gorengan singkong di Tabanan yang menghasilkan kulit $15 \mathrm{~kg} / \mathrm{hari}$. Bahan lainnya yaitu asam asetat $\left(\mathrm{CH}_{3} \mathrm{COOH}\right) 1 \%$, gliserol $\left(\mathrm{C}_{3} \mathrm{H}_{8} \mathrm{O}_{3}\right) 99 \%$, dan aquades.

Alat-alat yang digunakan pada penelitian ini yaitu baskom, kain saring, blender, saringan/ayakan 60 mesh, Hot plate strirer, magnetic strirer, oven Merk Labo Model DO 2116, cetakan Teflon (Maxim) diameter $20 \mathrm{~cm}$, gelas beaker $100 \mathrm{ml}$ (Herma), gelas beaker $250 \mathrm{ml}$ (Herma), timbangan analitik (ohaus pioneer), desikator, pipet tetes, pot plastik, thermometer, $\mathrm{pH}$ meter bA dan alat uji mekanik plastik berdasarkan ASTM D695-90.

\section{Rancangan Percobaan}

Rancangan percobaan pada penelitian ini yaitu Rancangan Acak Kelompok (RAK) faktorial dengan dua faktor. Faktor pertama yaitu suhu pada proses gelatinisasi pati kulit singkong yang terdiri dari 2 taraf yaitu :

$\mathrm{S} 1=70 \pm 1^{\circ} \mathrm{C}$ dan $\mathrm{S} 2=75 \pm 1^{\circ} \mathrm{C}$

Faktor kedua yaitu $\mathrm{pH}$ yang terdiri dari 4 taraf yaitu :

$\mathrm{P} 1=4, \mathrm{P} 2=5, \mathrm{P} 3=6$ dan $\mathrm{P} 4=7$

Kedua faktor tersebut menghasilkan 8 perlakuan kombinasi, dengan 3 kelompok berdasar waktu percobaan sehingga terdapat 24 unit percobaan. Data yang diperoleh dianalisis keragamannya dan dilanjutkan dengan uji perbandingan berganda Duncan.

\section{Preparasi pati kulit singkong}

Pembuatan pati kulit singkong dilakukan dengan cara sebagai berikut: kulit singkong atau lapisan kortek, dicuci sampai bersih. Kulit singkong yang sudah bersih ditambahkan air $(1: 4)$ untuk mempermudah proses penghancuran, kemudian dihaluskan dengan blender sehingga diperoleh bubur/pulp kulit singkong basah, selanjutnya dilakukan pemerasan dan penyaringan dengan kain saring. Cairan yang diperoleh berupa air pati ditampung dalam baskom dan diendapkan selama 12 jam untuk memperoleh endapan pati. Setelah terdapat endapan pada baskom tersebut, antara air dan endapan dipisahkan, di bagian atas endapan dibuang sehingga diperoleh endapan pati berwarna putih. Endapan pati yang diperoleh dikeringkan dengan oven pengering pada suhu $70^{\circ} \mathrm{C}$ sampai kadar air maksimal $11 \%$ setelah itu diayak dengan ayakan 60 mesh sehingga diperoleh pati kulit singkong yang halus.

\section{Proses pembuatan bioplastik}

Menimbang pati kulit singkong 
sebanyak 4 gram dan ditambah $100 \mathrm{ml}$ larutan asam cuka $\mathrm{pH}$ sesuai perlakuan. Campuran ditambah gliserol 1,5 gram dan diaduk hingga homogen. Kemudian dipanaskan di atas waterbath sambil diaduk pada suhu sesuai perlakuan selama 10 menit terbentuk gel.

Gel pati yang dihasilkan dituang pada cetakan Teflon dengan diameter $20 \mathrm{~cm}$, selanjutnya dimasukkan pada oven pengering pada suhu $65^{\circ} \mathrm{C}$ selama 5 jam. Setelah film terbentuk, Teflon yang masih terdapat film plastik dikeluarkan dari oven dan didiamkan dalam suhu kamar selama 24 jam.
Selanjutnya film plastik diambil dari Teflon dan siap diuji. Diagram alir pembuatan bioplastik dapat dilihat pada Gambar 1 .

\section{Variabel yang Diamati}

Variable yang diukur sifat fisik berupa pengembangan tebal sementara sifat mekanik yang diukur kekuatan tarik (tensile strength) (Gibson,1994), perpanjangan (elongation at break) (Gibson,1994) dan Modulus young (elastisitas) (Gibson,1994) dengan menggunakan alat uji tarik mengacu pada ASTM D695-90, Kemampuan biodegradasi (Harnist dan Darni, 2011).

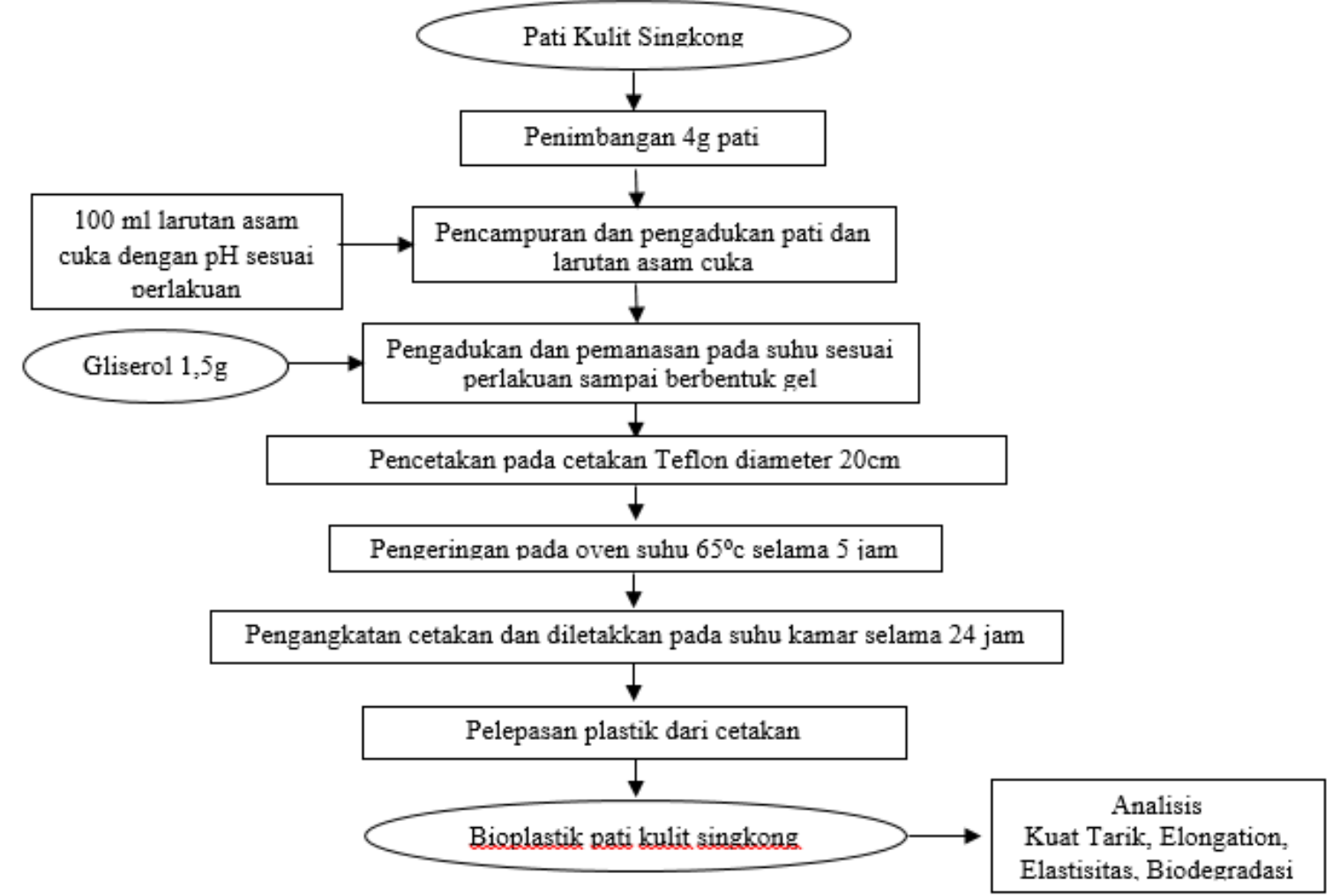

Gambar 1. Pembuatan bioplastik dari pati kulit singkong

\section{Pengembangan tebal}

Uji pengembangan tebal pada kondisi kering udara ditimbang tebal awalnya (T1) lalu direndam dalam air selama 24 jam kemudian diukur kembali tebalnya (T2).

keterangan:

$$
\mathrm{S}=\frac{\mathrm{T} 2-\mathrm{T} 1}{\mathrm{~T} 1} \times 100 \%
$$

$\mathrm{S}=$ Pengembangan tebal $(\%)$

$\mathrm{T} 2$ = Tebal Basah Rendam 24 jam $(\mathrm{cm})$
$\mathrm{T} 1=$ Tebal Awal $(\mathrm{cm})$

\section{Kekuatan Tarik (Tensile strength) (Gibson,1994) \\ Uji Kekuatan tarik atau tensile strength dilakukan dengan menggunakan alat yang mengacu pada ASTM D 695-90. Adapun cara pengujian yaitu: sampel dipotong sepanjang 8 $\mathrm{cm}$ dengan lebar $3 \mathrm{~cm}$, sampel dipasang di}


ragum uji tarik kemudian dial gauge diatur pada keadaan 0 , setelah itu dial gauge dihidupkan, handel diputar perlahan kekanan, sampai sampel putus kemudian data berupa gaya yang dikeluarkan dapat dilihat dial gaugle.

Berikut ini rumus perhitungan tensile strength: $\sigma=\mathrm{F} / \mathrm{A}$

Keterangan:

$F \quad$ = Gaya yang diperlukan $(\mathrm{N})$

$\mathrm{A}=$ Luas Pemukaan $\left(\mathrm{mm}^{2}\right)$

$\sigma=$ Tensile Strength $\left(\mathrm{N} / \mathrm{mm}^{2}\right)$

Perpanjangan Saat Putus Bioplastik (Elongation at break) (Gibson,1994)

Uji perpanjangan atau elongation dilakukan dengan menggunakan alat uji tarik mengacu pada standar ASTM D 695-90. Adapun cara pengujian yaitu: sampel dipotong sepanjang $8 \mathrm{~cm}$ dengan lebar $3 \mathrm{~cm}$, sampel dipasang di ragum uji tarik dimana sampel yang diuji sepanjang 4,46 $\mathrm{cm}$, kemudian dial gauge diatur pada keadaan 0 , setelah itu dial gauge dihidupkan, handel diputar kekanan, sampai sampel putus kemudian, dicatat perubahan panjang pada sampel. Berikut ini rumus perhitungan elongasi (\%):

Elongasi $(\%)=\frac{\text { Perpanjangan film }(\mathrm{mm})}{\text { panjang awal film }(\mathrm{mm})} \times 100 \%$
Elastisitas (Modulus Young) (Gibson,1994)

Modulus young (Elastisitas) diperoleh dari perbandingan antara kuat tarik dengan elongasi. Berikut ini rumus perhitungan modulus young elastisitas):

$$
\text { Elastisitas }(\mathrm{MPa})=\frac{\text { Kuat Tarik }(\mathrm{MPa})}{\text { Elongasi }(\%)}
$$

\section{Kemampuan Biodegradasi (Harnis dan Darni, 2011)}

Sifat biodegradable film diuji dengan cara mengubur plastik dalam tanah kompos dengan kedalaman $10 \mathrm{~cm}$ (Ardi, 2009). Pengujian biodegradable dilakukan dengan proses penguburan plastik selama 1 minggu kemudian diamati setiap 24 jam. Hasil terbaik didapat dari perlakuan yang lebih awal terdegradasi.

\section{HASIL DAN PEMBAHASAN}

\section{Kuat tarik bioplastik}

Berdasarkan hasil analisis keragaman pengaruh suhu dan $\mathrm{pH}$ pada proses pembuatan bioplastik pati kulit singkong berpengaruh sangat nyata $(\mathrm{p}<0,01)$ terhadap kekuatan tarik. Nilai kekuatan tarik sampel terdapat pada Gambar 2.

$$
\text { x } 100 \%
$$

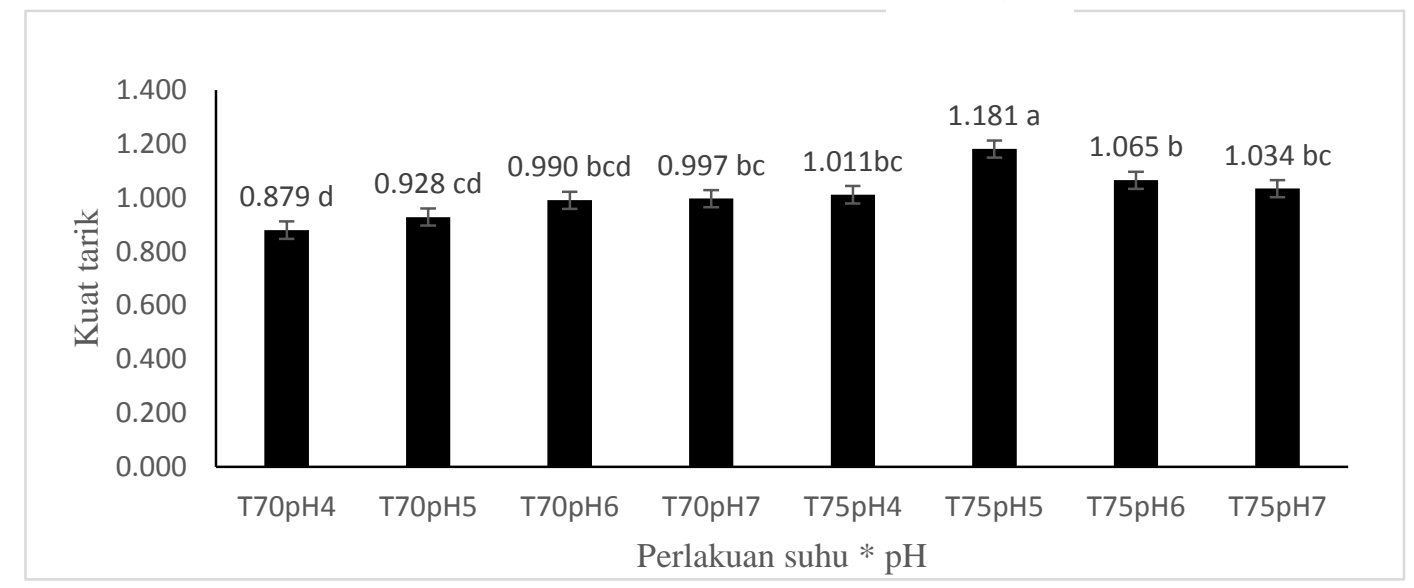

Gambar 2. Diagram batang nilai rata-rata kuat tarik bioplastik dari pati kulit singkong (MPa)

Pada gambar terlihat kekuatan tarik tertinggi terdapat pada sampel dengan suhu 
$75^{\circ} \mathrm{C}$ dan pH5 dengan nilai 1.181 MPa. Kekuatan tarik terendah terdapat pada sampel dengan suhu $70^{\circ} \mathrm{C}$ dan $\mathrm{pH} 4$ dengan nilai $0.878 \mathrm{MPa}$. Plastik biodegradable dari pati kulit singkong tidak memenuhi nilai kekuatan tarik berdasarkan standar plastik internasional (ASTM5336) untuk plastik PLA dari Jepang yang memiliki nilai minimum $2.050 \mathrm{Mpa}$, tetapi memenuhi standar plastik Inggris untuk PC plastik yang memiliki nilai minimal sebesar $190 \mathrm{MPa}$ (Averous, 2009). Dalam penelitian Purwanti (2010) juga disimpulkan bahwa film dari kitosan murni memiliki nilai kuat tarik lebih tinggi jika dibandingkan dengan kitosan yang telah dicampur bahan lain tetapi nilai elongasi yang dihasilkan lebih rendah. Bioplastik dengan kekuatan tarik yang tinggi akan mampu melindungi produk yang dikemasnya dari gangguan mekanis dengan baik.

\section{Perpanjangan saat putus}

Perpanjangan putus (elongation) merupakan persen pertambahan panjang bahan materi film yang diukur mulai dari panjang awal pada saat mengalami penarikan hingga putus. Berdasarkan hasil analisis keragaman pengaruh $\mathrm{pH}$ dan suhu pada proses pembuatan bioplastik pati kulit singkong berpengaruh nyata $(\mathrm{p}<0,05)$ terhadap perpanjangan saat putus. Nilai kekuatan tarik sampel terdapat pada Gambar 3.

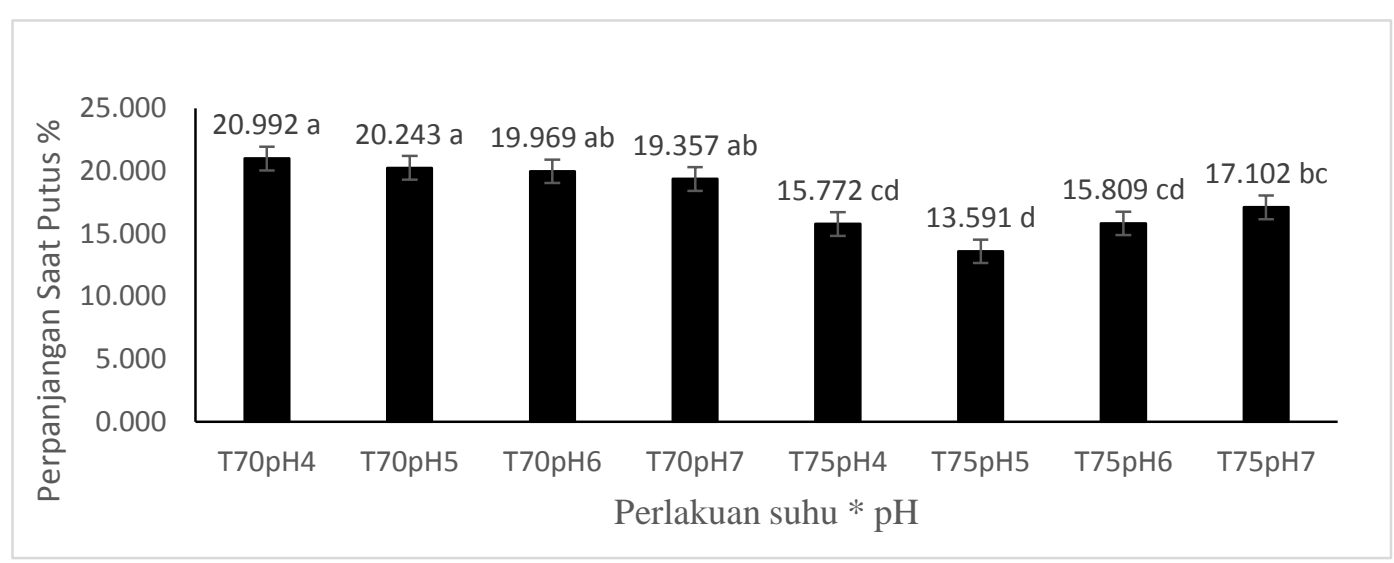

Gambar 3. Diagram batang nilai rata-rata perpanjangan saat putus bioplastik dari pati kulit singkong (\%)

Perpanjang saat putus (elongation at break) atau proses pemanjangan merupakan perubahan panjang maksimum pada saat terjadi peregangan hingga sampel film terputus. Pada umumnya adanya penambahan plasticizer dalam jumlah lebih besar akan menghasilkan nilai persen pemanjangan suatu film semakin lebih besar. Tanpa penambahan plasticizer, amilosa dan amilopektin akan membentuk suatu film dan struktur dengan satu daerah kaya amilosa dan amilopektin. Interaksi antara molekulmolekul amilosa dan amilopektin mendukung formasi film, menjadikan film pati jadi rapuh dan kaku (Kristiani, 2015).
Pada Gambar 3 terlihat nilai perpanjangan saat putus tertinggi didapat pada sampel dengan suhu $70^{\circ} \mathrm{C}$ dan $\mathrm{pH} 4$ dengan nilai 20,992\%. Perpanjangan saat putus terendah terdapat pada sampel dengan suhu $75^{\circ} \mathrm{C}$ dan $\mathrm{pH} 5$ dengan nilai $13,591 \%$. Nilai perpanjangan tertinggi saat putus lebih besar dibandingkan penelitian yang dilakukan Harsojuwono et al (2017), sebesar $10,32 \%$. Hasil penelitian ini sudah memenuhi standar plastik internasional (ASTM5336) yang menetapkan nilai elongation at break kurang dari 500\% untuk PCL dari Inggris, meskipun untuk standar PLA dari Jepang belum terpenuhi, tetapi sudah mendekati 
batas nilai maksimal elongation at break-nya sebesar $9 \%$.

\section{Elastisitas}

Berdasarkan hasil analisis keragaman pengaruh $\mathrm{pH}$ dan suhu pada proses pembuatan bioplastik pati kulit singkong berpengaruh sangat nyata $(\mathrm{p}<0,01)$ terhadap kekuatan tarik. Nilai elastisitas sampel terdapat pada Gambar 4.

Pada Gambar 4 terlihat elastisitas tertinggi terdapat pada sampel dengan suhu $75^{\circ} \mathrm{C}$ dan pH5 dengan nilai 8,744 MPa. Elastisitas terendah terdapat pada sampel dengan suhu $70^{\circ} \mathrm{C}$ dan $\mathrm{pH} 4$ dengan nilai 4,197 MPa. Hasil nilai dari penelitian ini memiliki nilai jauh lebih kecil dari pada penelitian yang dilakukan Harsojuwono et al (2017), memiliki nilai elastisitas sebesar 6629,47 MPa. Elastisitas yang tinggi akan berpengaruh terhadap produk yang akan dikemas untuk keutuhan produk (Harsojuwono et al, 2017).

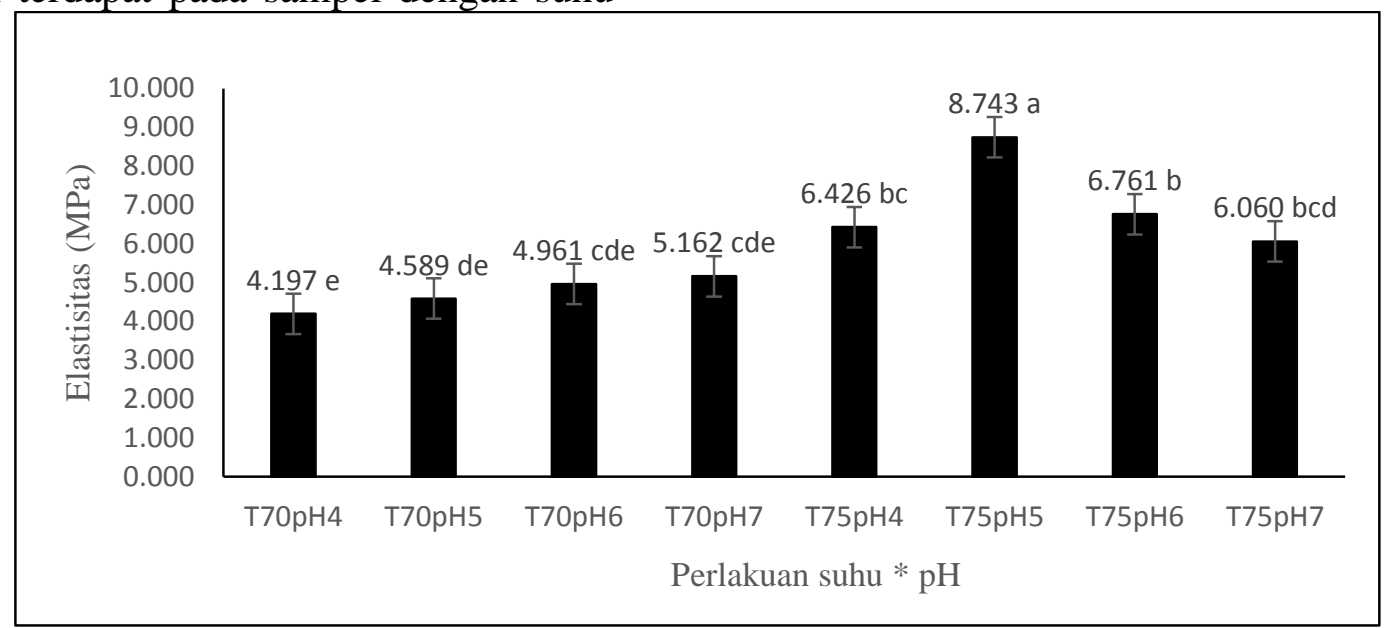

Gambar 4. Diagram batang nilai rata-rata elastisitas bioplastik dari pati kulit singkong (MPa).

\section{Ketebalan}

Berdasarkan hasil analisis keragaman pengaruh $\mathrm{pH}$ dan suhu pada proses pembuatan bioplastik pati kulit singkong berpengaruh tidak nyata $(p>0,05)$ terhadap kekuatan tarik. Nilai ketebalan sampel terdapat pada Gambar 5.

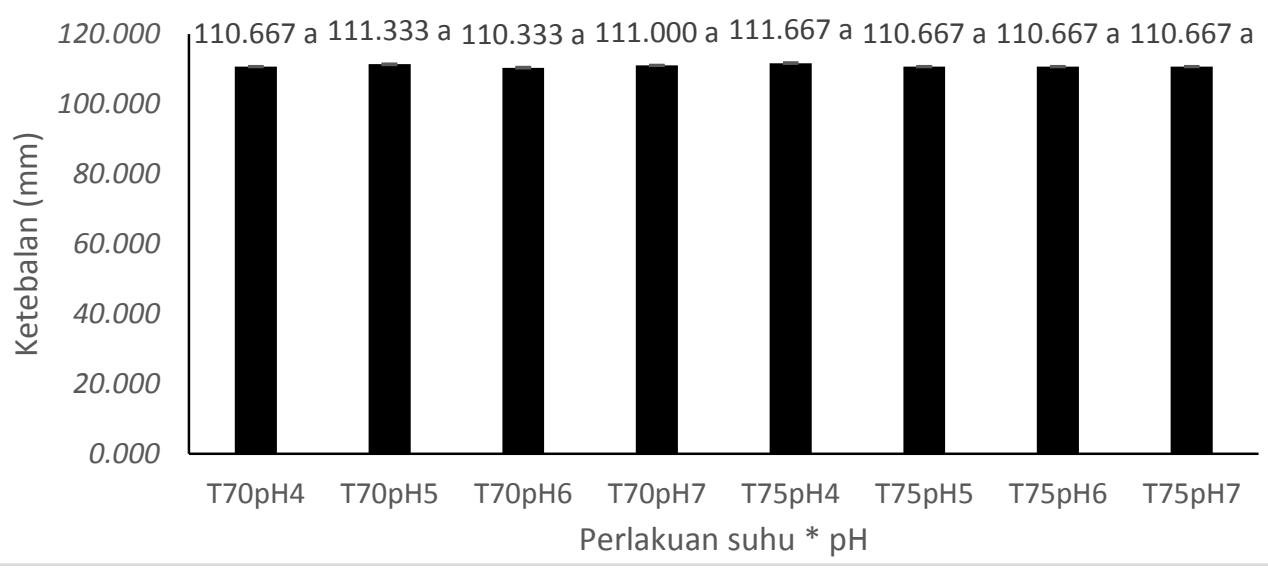

Gambar 5. Diagram batang nilai rata-rata nilai ketebalan bioplastik dari pati kulit singkong $(\mathrm{mm})$ 
Pada Gambar 5 ketebalan tertinggi terdapat pada sampel dengan suhu $75^{\circ} \mathrm{C}$ dan pH 5 dengan nilai $111,667 \%$. Sementara untuk suhu dan $\mathrm{pH}$ lainnya memiliki hasil yang bervariasi. Hasil penelitian ini lebih tinggi jika dibandingkan pada penelitian yang dilakukan oleh Harsojuwono et al, (2017), yang menunjukan nilai pengembangan berkisar 9,91\% - 11,28\%. Ketebalan film dipengaruhi oleh banyaknya total padatan dalam larutan dan ketebalan cetakan. Dengan cetakan yang sama, film yang terbentuk akan lebih tebal apabila volume larutan yang dituangkan ke dalam cetakan lebih banyak. Demikian juga dengan total padatan yang akan membentuk film menjadi lebih tebal dengan jumlah yang lebih banyak. Ketebalan bioplastik tidak memberikan pengaruh yang signifikan terhadap kuat tarik dan persen pemanjangan. Yang mempengaruhi kuat tarik dan persen pemanjangan adalah komposisi dari film bioplastik tersebut (Harsojuwono et al, 2017).

\section{Biodegradasi}

Proses biodegradabilitas dapat terjadi dengan proses hidrolisis (degradasi kimiawi), bakteri/jamur, enzim (degradasi enzimatik), oleh angin dan abrasi (degradasi mekanik), cahaya (fotodegradasi). Proses ini juga dapat dilakukan melalui proses secara anaerobik dan aerobik. Pada penelitian ini uji biodegradasi dilakukan dengan cara mengubur sampel kedalam tanah dengan kedalaman $10 \mathrm{~cm}$ dalam waktu 7 hari.

Berdasarkan hasil analisis yang dilakukan dengan cara mengubur bioplastik di dalam tanah dengan kedalaman $10 \mathrm{~cm}$ maka diperoleh data seperti Tabel 1 .

Tabel 1 diatas menunjukkan bahwa penguburan mendapatkan hasil T70pH4 dan T75pH7 umur degradasi selama 5 hari. T70pH5 dan T75pH5 umur degradasi selama 3 hari, T70pH6 umur degradasi selama 2 hari, T70pH7, T75pH4 dan T75pH6 umur degradasi selama 4 hari. Berdasarkan hasil analisis, untuk hasil terbaik degradasi bioplastik yaitu bioplastik dengan perlakuan T70pH6.

Tabel 1. Hasil analisis biodegradasi pada bioplastik

\begin{tabular}{cc}
\hline Perlakuan & waktu degradasi (hari) \\
\hline T70pH4 & 5 \\
T70pH5 & 3 \\
T70pH6 & 2 \\
T70pH7 & 4 \\
T75pH4 & 4 \\
T75pH5 & 3 \\
T75pH6 & 4 \\
T75pH7 & 5 \\
\hline
\end{tabular}

\section{KESIMPULAN DAN SARAN}

\section{Kesimpulan}

Berdasarkan penelitian yang telah dilakukan maka dapat disimpulkan beberapa hal sebagai berikut :

1. Perlakuan interaksi antara suhu dan $\mathrm{pH}$ memiliki pengaruh sangat nyata pada kuat tarik bioplastik $(\mathrm{p}<0,01)$ dan elasisitas $(\mathrm{p}<0,01)$. Perlakuan suhu dan $\mathrm{pH}$ pada perpanjangan saat putus Berpengaruh nyata $(\mathrm{p}<, 0,05)$, perlakuan ketebalan berpengaruh tidak nyata ( $>0,05)$, biodegradasi terbaik didapat pada perlakuan T70pH6 pada pembuatan bioplastik dari bahan pati kulit singkong.

2. Berdasarkan analisis yang dilakukan pada sampel bioplastik pati kulit singkong terbaik terdapat pada perbandingan suhu $75^{\circ}$ dan $\mathrm{pH} 5$ dengan karakteristik kuat tarik sebesar 1,181Mpa, perpanjangan saat putus sebesar 13,591\% , elastisitas sebesar 8,744Mpa dan degradasi terbaik didapat pada pengujian sampel S1P3 yang terdegradasi selama 2 hari

\section{Saran}

Berdasarkan penelitian ini, dapat disarankan untuk menggunakan 
perbandingan suhu pemanasan $75^{\circ} \mathrm{C}$ dan $\mathrm{pH}$ 5 untuk melarutkan bahan, sehingga akan mendapatkan hasil bioplastik pati singkong yang paling optimum.

\section{DAFTAR PUSTAKA}

Averous, P.L. 2009. Bioplastics Biodegradable Polyesters (PLA, PHA,PCL). :http : // www. biodeg. net/bioplastic.html. (Diakses pada tanggal 25 Mei 2015).

Coursey, D.G.1973.Cassava as food: Toxicity and of Interdisplinary Workshop, London, England.

Gibson, R, F. 1994. Principles Of Composite Material Mechanics.NewYork : Mc Graw Hill,Inc

Grace, M.R. 1977. Cassava Processing. Food and Agriculture Organization ofUnited Nations. Roma.

Griffin, G. J. L. 1994. Chemistry and Technology of Biodegradable Polimer. London : Chapman \& Hall.

Harnist, R. D, Y. 2011. Penentuan Kondisi Optimum KonsentrasiPlasticizer padaSintesa Plastik Biodegradable
Berbahan Dasar Pati

Sorgum.Universitas Lampung,Seminar Nasional Sains dan Teknologi-II.

Harsujuwono, B.A., Arnata, I W., Mulyani, S. 2017. Karakteristik Bioplastik Pati Singkong Termodifikasi Dalam Variasi Suhu Dan pH Gelatinisasi. Universitas Udayana Bali.

Richana, N. 2013. Mengenai Potensi Ubi Kayu \& Ubi Jalar. Nuansa Cendikia: Bandung.

Salim, E. 2011. Mengolah SingkongMenjadi Tepung Mocaf Bisnis Produk Alternatif pengganti Terigu. Yogyakarta: Lily Publisher.

Supriyadi. 1995. Pengaruh tingkat penggunaan hasil fermentasi kulit ubi kayu oleh jamur Asfergillus niger dalam ransum terhadap performan ayam pedaging periode starter. Skripsi. Universitas Padjadjaran, Bandung

Yuniarti, L.I., G.S. Hutomo dan A. Rahim. 2014. Sintesis dan Karakterisasi Bioplastik Berbasis Pati Sagu (Metroxylon sp). e-Journal Agrotekbis 2 (1) :38-46.ISSN : 2338-3011 